\title{
Dynamical Seasonal Fluctuations of the Prevailing Insect-Pests on Faba Bean and Garden Pea Plantations at Alexandria Governorate, Egypt
}

\author{
Hassan A.Mesbah, Osman A.Zaghloul ${ }^{1}$, Nagda A.El-sayed, ${ }^{1}$ Nabil A. Hassan ${ }^{2}$, Rania S.Ammar ${ }^{2}$
}

\begin{abstract}
A survey of insect- pests and beneficial -insects of faba bean and garden pea plants was conducted during the consequent growing seasons of 2014-2015 and 2015-2016 at Abis, Alex. Egypt.

The identified insect- pests of faba beans foliage implied 4 species: Liriomyza trifolii (Burgess), Aphis craccivora (Koch.), Bemisia tabaci (Gennadius)and Emposca lybica(De Berg.). The highest recorded number of inspected insects was aphid, versus the lowest recorded one of $E$. lybica, throughout both the consequent seasons of (2014-2015) and (2015-2016).
\end{abstract}

The two inspected and identified insect species on garden peas foliage were Liriomyza trifolii and Bemisia tabaci. Leafminer was recorded at highest numbers throughout both the growing seasons.

Additionally both the detected lepidopteran insects; the blue butterfly, Cosmolyce baeticus Polyommatus and bean pod borer,Etiella zinckenella Treitschke injuriously infested faba beans and garden peas pods. Where as, C.baeticus has been registered at high numbers on faba bean pods during both the growing seasons, versus E.zinckenella, which was relatively high of garden peas pods.

The three inspected and identified beneficial insect species on faba beans plants were Diglyphus isaea (Walker) (Or.Hymenoptera) Chrysoperla carne (Stephens) (Or. Neuroptera) \& Coccinella undecimpunctate (Linnaeus) (Or.Coleoptera). The calculated numbers of parasitoids and predators on faba bean plants increased as the number of their hosts increased. The calculated number of (Diglyphus isaea) was relatively high followed by Chrysoperla carnea and Coccinella undecimpunctate in both the growing seasons.

Two species of natural enemies were also inspected and identified on garden peas plants, ie. D. isaea and C. undecimpunctate. D. isaea was recorded as the highest number of the natural enemies, and $C$. undecimpunctata as the lowest number of inspected predators.

Key words: faba bean, garden peas, survey and fluctuation

\section{INTRODUCTION}

Faba bean (Vicia faba L.) is the most important annual pulse crop grown worldwide. It is one of the promising pulse crops, which can play an important role in increasing legume production in Egypt.Seeds are used for human nutrition as seeds have $28 \%$ protein, $58 \%$ carbohydrate and 2\%fat (Köpke and Nemecek 2010).The cultivated area of faba bean has been decreased in the last three years in Egypt from 34871 to 26700 ha (FAO,2014).Besides it contributes as fodder to feed livestock and also affect positively the soil productivity for the cereal crops grown in rotation (Zeghouane, 1991).

Garden peas (Pisum sativum L.) is among the most popular vegetable crops in Egypt.It has a great nutritional value because of its higher components of protein(7.0g), calcium(25mg),phosphorous (124mg), thiamin, riboflavin,niacin and ascorbic acid $(0.38,0.14$, 2.3 and $26 \mathrm{mg} / 100 \mathrm{~g}$ seed, respectively) (Pellet and Shadarevian, 1970). In Egypt, the cultivated area with garden peas comprises 53874 acres and the annual production is about 38.843 thousands tons dry seeds (A.O.A.D.Satis. year book, 2012). United States, India ,Russia, England and France are among the first great producers of peas.

Unfortunately, faba beans and garden peas crops are subjected to the attack by several insect pests, right from the early stage of plant growth throughout its late development stage up to post-harvest and grains storage. Many insects belonging to the orders Lepidoptera, Diptera, Hemiptera, Thysanoptera and Coleoptera are known to attack faba bean. But, the major pests are the legume leaf miners(Liriomyza trifolii), aphids (Aphis craccivora), whitefly (Bemisia tabaci) and leafhopper (Emposca lybica) on the foliage of faba bean plants.Additionally the blue butterfly (Cosmolyce baeticus) and bean pod borer (Etiella zinckenella) infesting pods ( Lanzoni et al. 2003).

Therefore, the present study was conducted to

1- survey and identification of the found insect-pests and natural enemies species on faba bean and garden pea plants,

2- study the seasonal fluctuations of these insects during the growing seasons of (2014-2015) and (2015-2016), and

\footnotetext{
${ }^{1}$ Plant protection Department, Faculty of Agric.,Saba-Bacha,

Alex.Univ., Egypt.

${ }^{2}$ Plant protection Research Institute, Agric. Res.,

Center,El-sabaheia, Alex

Received November 9, 2016, Accepted December 12, 2016
} 
3- Determe the relationship between the inspected insect-pests and prevailing temperature and relative humidity in the field.

\section{MATERIALS AND METHODS}

\section{Experimental site and design:}

Field experiments were carried out during the successive growing seasons of (2014-2015) and (20152016) at the Experimental Farm of the Agricultural Research Station, Faculty of Agriculture, Alexandria University at Abis,Alex.,Egypt.

One variety of faba bean (Giza planka) and one variety of garden pea (master B) were used in the initiated experimental study. The experimental area of each of faba beans and garden peas was $390 \mathrm{~m}^{2}$ $(6 \times 65 \mathrm{~m})$, nearly 2 kirats. The seeds were sown in hills at distance of $20-25 \mathrm{~cm}$ apart, and in rows of $70 \mathrm{~cm}$ width. The normal agricultural practices were followed as recommended by the Egyptian Ministry of Agriculture and recommendation guidance. The sowing date of run cultivations was fixed and occurred on the $2^{\text {nd }}$ half of November in both growing seasons of (20142015) and (2015-2016).

Survay of pests attacking faba bean and garden pea plants:

the survey of the main insect pests attacking the different stages of growing plant was performed throughout the elapsed period from 21 December (Winter) till 7 April (Spring) under field condition,for studying the seasonal numerical variations of detected insects along the interval of perforemed inspection dates.Samples of plant leaves and /or pods were collected weekly. Infestations by the main of insectpests faba bean and garden pea plants were observed and recorded .

Sampling techniques were differed according to the detected pests and their stage. For the purpose of detecting the incidence of the leafminer (larvae) ,whitefly (immature), aphids and leaf hoppers (immature,aduts) regarding to natural enemies the parasite Diglyphus isaea was counted as larvae, while the predators Chrysoperla, Coccinella undecimpunctate were counted as adults. Samples of 15 plants of faba bean and garden pea were randomly collected, put in polyethylene bags and transferred immediately to the laboratory. The three parts of plant canopy (lowermedium-upper) were carefully examined using a stereoscopic binocular microscope for counting the numbers of leafminer larvae inside their mines; they made between the upper and lower leaf surface, as to the immature stages of whitefly, aphids and leaf hoppers counted / 45 leaves (15 plants).
Natural enemies have been inspected and counted on 15 randomly plants from each plot in the field.

Inspection of blue butterfly and the bean pod borer larvae on the sampled premature and full mature pods,was performed.The pods were weekly taken at random from the 15 plants at a rate of three pods/ plant.They were examined in the laboratory to record the number of larvae .

Data were subjected to the analysis of variance test (ANOVA) as randomized complete block design. The least significant differences (LSD) at the 5\% level were determined using a computer program (Costat) and Duncan's Multiple Range testes modified by Steel and Torrie (1981) and LSD values were used to compare the mean numbers of inspected pest infestation.

\section{RESULTS AND DISCUSSION}

\section{A-Survey of the prevailing insect- pests and their natural enemies on faba bean and garden pea plants:}

The inspected insect pests of faba bean and garden pea foliage were identified and classified;they included 4 species infesting faba beans,i.e,(Liriomyza trifolii), (Aphis craccivora), (Bemisia tabaci) and(Emposca lybica). While the main pests of garden pea were $L$. trifolii and Bemisia tabaci .

The pods of faba bean and garden pea were attacked by the lepidopterous butter flies(Cosmolyce baeticus) and (Etiella zinckenella).

Concerning numbers of natural enemies, three inspected and identified natural enemies in the present investigation on faba bean $D$. isaea, $C$. undecimpunctate and C. carnea, and two identified natural enemies presented on garden pea plants $D$. isaea and C. undecimpunctate.

B- Population fluctuation of insect pests and their natural enemies on faba bean plants during the two growing seasons (2014-2015) and (20152016):

As shown in table (1), during the growing season of (2014-2015) etc. The mean numbers of leafminers was $(1 \pm 0.58)$ and a range of $(0-2)$ insects/45 leaves by the end of December 2014 under the prevailing higrothermic conditions of $14^{\circ} \mathrm{C}$ and $60 \%$ R.H $\%$. While that number of inspected leafminers did not excecd (64 \pm 0.88 ) with a range of (60-69) individuals $/ 45$ leaves in the beginning of April 2015 corresponding to $19^{\circ} \mathrm{C}$ and R.H\%. of $73 \%$.

Statistical analysis showed that there were highly significant differences between the inspection periods and, the rates of detected leafminers insects. 


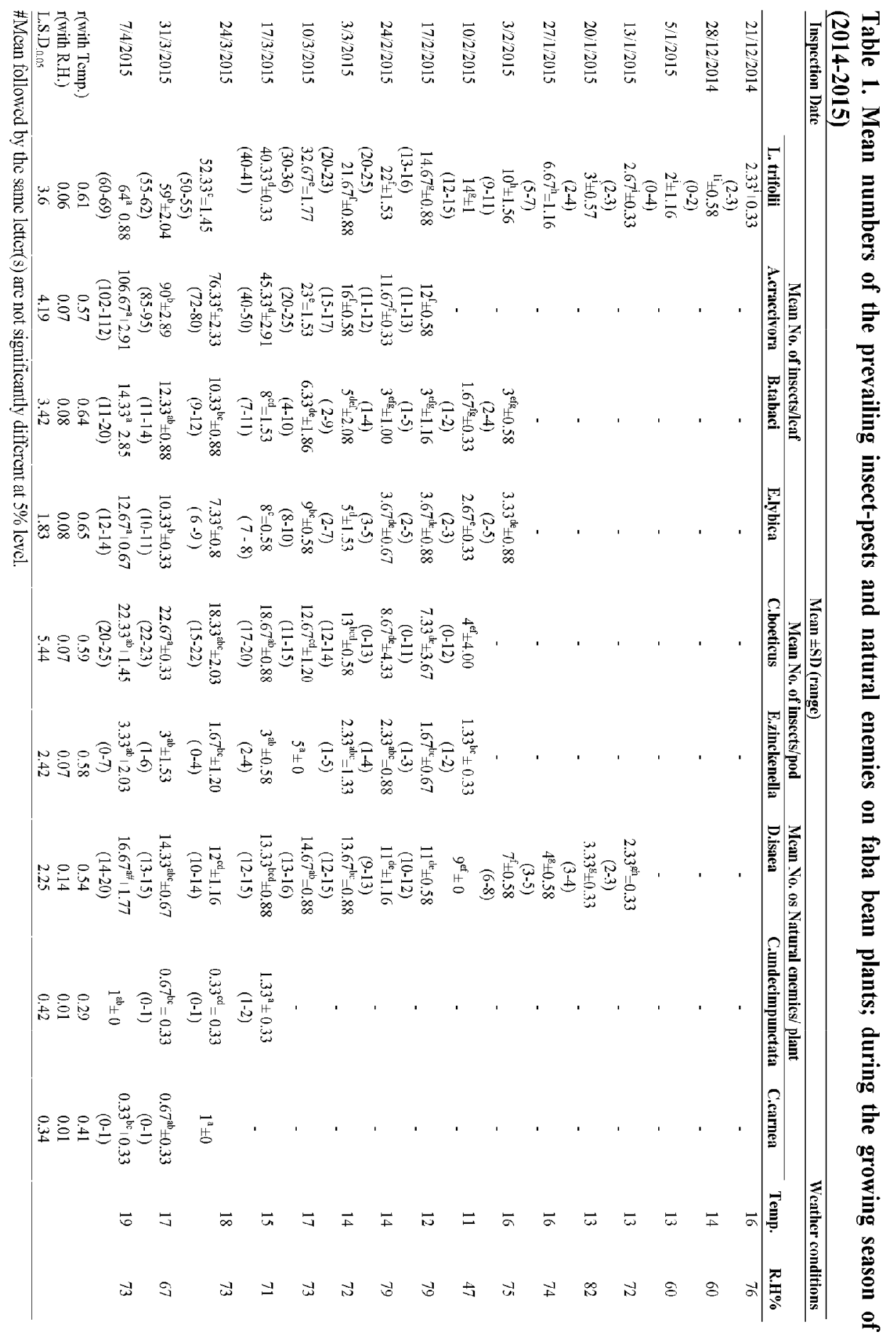


In addition, $A$ craccivora started to appear in the $2^{\text {nd }}$ half of Februry, whereas, the measured number of the aphids started to grow up as temperature increased. The highest calculated mean number of $(106.67 \pm 2.91)$ with a range of (102-112 insects/ 45 leaves) individuals in the first week of April at the prevailing temperature of $19{ }^{\circ} \mathrm{C}$ and $73 \%$ R.H.

The numbers of both of whitfly and leafhoppers increased as the temperature increased table(1). Their recorded mean numbers equaled $3 \pm 0.58$ and $3.33 \pm 0.88$ with ranges (2-4) and (2-5) insects/45leaves, in respect at $16^{\circ} \mathrm{C}$ and relative humidity $75 \%$ in the first week of February, then gradually increased till reaching their Maximum numbers during the first week of April their means numbers amountedto $14.33 \pm 2.85$ and $12.67 \pm$ 0.67 and ranges of (11-20) and (12-14) insects/45leaves.

Because, the population increase of both insect-pests need a suitable condition of high temperature above 19 ${ }^{0} \mathrm{C}$.This thermic conditions were not available during the period of winter season plantation(Decemberfebruary) and led to the reduced detected numbers of them. These results are in agreement with those of Schuster and patel (1985).

Moreover,the performed correlation between the prevailed temperature and the mean number of the leafminers showed a strong positive relationship( $r$ value of 0.61 ), aphid, also showed a positive strong relationship with temperature $\mathrm{r}=0.57$ during the same period of inspection.On the contrary, the number of whitefly and leafhopper increased as the temperature increased giving a positive strong relationship $(\mathrm{r}=0.64$ and 0.65 , successively).

Statistical analysis showed that there was a positive weak relationship between the prevailing relative humidity(R.H.\%) throughout the season. The population of each of leafminer, aphid, whitfly and leaf hopper $(\mathrm{r}=0.06,0.07,0.08$ and 0.08 , in respect)(table,1).

With regad to the other detected insect-pests, lately infesting pods of both faba bean at the end of the growing season, two species were inspected Cosmolyce baeticus and Etiella zinckenella recorded a low mean number of $(4 \pm 4.00$ and $1.33 \pm 0.33)$ with ranges of (0-12 \&1-2) individuals, insects/45pods in mid February at $11^{\circ} \mathrm{C}$ and $47 \%$ of R.H\%. The highest $(22.67 \pm 0.33)$ mean number of $C$. baeticus was found in the last day of March, while in E. zinckenella the highest $(5 \pm 0)$ individuals mean number was observed in mid March. (Table, 1 ), at $17{ }^{\circ} \mathrm{C}$ and 73 of \% R.H.

The prevailing conditions of temperature and relative humidity were suitable for both insects as the number of both insects started to be increased when the temperature increased.
Statistical analysis signified a positive relationship between the incidence of $C$. baeticus and E. zinckenella with the prevailing temperature $(\mathrm{r}=0.59$ and 0.58 ,subsequently).The correlation coefficient was positively weak with the relative humidity(R.H.\%)(r=0.07 and 0.07 ,in respect) during that season. Table (1).

The prevalent beneficial insect- species on faba bean plants, these surveyed insects were also classified as defined below:

- D. isaea which was collected in relatively highest mean numbers of $(16.67 \pm 1.77)$, by 7 th April, respectively table(1).

- C. undecimpunctate which was collected in a comparatively lower estimated mean number representing $(0.33 \pm 0.33)$ insects/ plant 24 th of March .

- C. carnea which was also found in a relatively comperatively low mean number of $(0.33 \pm 0.33)$ insects / plant on 7th of April, respectively.

The relationship between the $D$. isaea individuals were positive with either temperature or the relative humidity ( $\mathrm{r}=0.54$ and 0.14 , respectively).

Statistical analysis referred to a positive relationship between the prevailing temperature and the number of C. undecimpunctate individuals $(\mathrm{r}=0.29)$, the correlation coefficient $(\mathrm{r}=0.01)$ was positively weak with the relative humidity R.H.(Table, 1).

From the above cited results it could be concluded that, $D$. isaea was abundant when the calculated number of leaf miner was very hight. In other words the population reflected the number of that ecto-parasitoid (D.isaea) with the increase in temperature.The natural ememies prove a positive relationship with temperature and R.H\%.

These results are in agreement with those of Doss et al. (1992) who founded that leaf miner infestation began with low numbers on December, then increased gradually till March and declined by the end of April (that was the period of inspection in the present study).

Statistical analysis showed that there were highly significant differences between the inspection periods and, the rates of detected aphids, whitfly, leafhoppers,pod borer insects and natural enemies.

Table (2) presented the population densities of the injurious insect-pests infesting faba bean plants during the growing season of (2015-2016). It was noticed that the aphidsand whitefly started its population from the last week of January (2016) with the mean number of (2 \pm 0.58 and $6.33 \pm 1.86)$ and a range of (1-2)\& (4-10)insects/45 leaves, individuals, respectively, at the temperature of $10^{\circ} \mathrm{c}$ and $81 \%$ R.H. $\%$, 


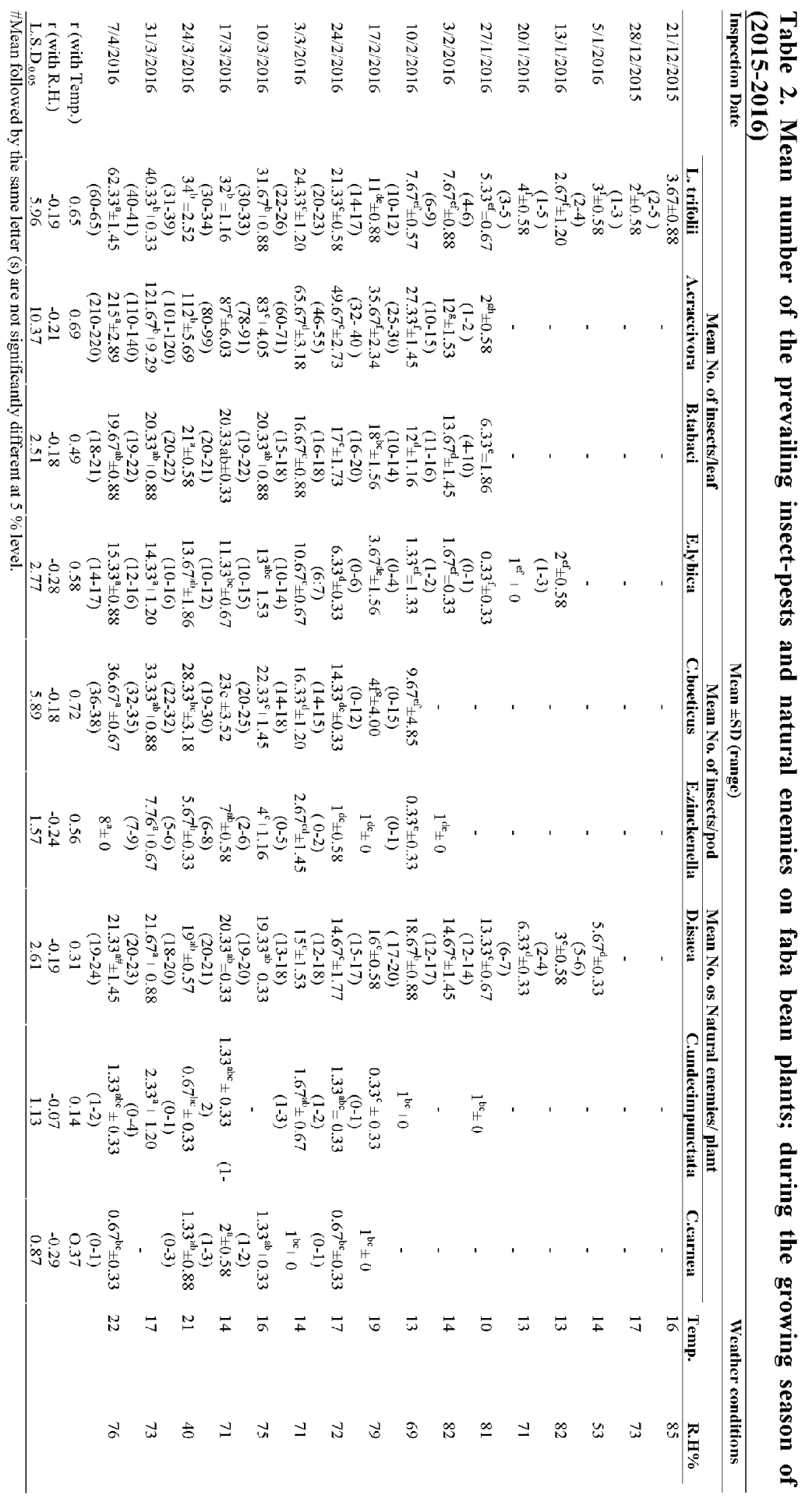


till the end of inspection period (first week of April 2016) their populations increased gradually with the mean numbers of $215 \pm 2.89$ and $19.67 \pm 0.88$ insects /leaf, respectively, at the prevailing temperature of 22 ${ }^{0} \mathrm{C}$ and $76 \%$ R.H.

Statistical analysis showed a positive strong relationship between the incidence of the whitefly\& aphids and the temperature $(r=0.69$ and 0.49$)$ in respect. This relationship was a negative the prevailing R.H. \% ( $\mathrm{r}=-0.21$ and -0.18 , respectively) (Table ,2).

On the contrary, the counted number of leafminer started to increase by the end of December 2015, with the mean number of $(3.67 \pm 88)$ and a range of $(2-5$ insects/45leaves), individuals at the temperature $16^{\circ} \mathrm{C}$ and $85 \%$ R.H.\%, table(2). The highest level of this insect was recorded in the first week of April (62.33 \pm $1.45)$ with a range of (60-65)/45leaves.

Statical analysis showed a positive relationship between the prevailing temperature and the number of the insect individuals $(\mathrm{r}=0.65)$, while the correlation coefficient was negative with the relative humidity R.H. $\% \mathrm{r}=-0.19$ (Table,2).

The jassid started to appeared in the $2^{\text {nd }}$ week of January $2016(2 \pm 0.58)$ with temperature of $13^{\circ} \mathrm{C}$ and $82 \%$ R.H.\% the highest level $(15.33 \pm 0.88)$ was witnessed in the first week of April. The relationship between jassid population and the temperature was positive $(\mathrm{r}=0.58)$, while it was negative with R.H.\% $(\mathrm{r}=-0.28 \%)$ R.H. Table (2).

Regarding the pod borers, $C$. baeticus was considered to be a severely injurious economic insectpest on faba bean pods. Since it has been registered at ratherly high numbers and then increased to shows the highest mean numbers of $(36.67 \pm 0.67)$ during the first week of April as the temperature increased to $22{ }^{\circ} \mathrm{C}$ (table, 2).

E. zinckenella was found in low levels from the first week of February to the first week of March then increased to record the highest level during the first week of April ( $8 \pm 0)$ insect/pod.

The relationship between the temperature and mean number of either C. baeticus or E. zinckenella showed that there was a positively high relationship $(r=0.72$ and 0.56 , in respect) and negatively with R.H.\% ( $r=-0.18 \%$ and $-0.24 \%$, successively) (Table, 2 ).

The mean number of the natural enemies D.isaea, C. undecimpunctata and C. carnea were prevalented along the growing season (2015-2016) giving the highest calculated number of individuals $(21.33 \pm 1.45$, $1.33 \pm 0.33$ and $0.67 \pm 0.33$ ), in respect, during the first week of April at the prevailing temperature of $22{ }^{\circ} \mathrm{C}$ and $76 \%$ R.H.(Table, 2).
There was a negative correlation $(r=-0.29)$ between the prevailing relative humidity (R.H.\%)and the number of individuals of E. zinckenella meanwhile, there was a lower positive relationship between R.H. and

$$
\text { C. baeticus }(\mathrm{r}=0.12) \text { (Table, 2). }
$$

There was a positive correlation between temperature and the population of D. isaea ,C. undecimpunctata and $\mathrm{C}$. carnea $(\mathrm{r}=0.31,0.14$ and 0.37),respectively. While there was a negative relationship $r=(-0.19,-0.07$ and -0.29$)$ between the prevailing relative humidity R.H.\%. (table,2).

\section{C- Population fluctuation of insect pests and their natural enemies on garden pea plants during two growing seasons (2014-2015) and (2015-2016):}

Table,3 showed the detect insects during the growing season of (2014-2015), the mean number of leafminer was very low $(1.67 \pm 1.15)$ and a range (1-3) individuals / 45 leaves by the end of December 2014. The highest mean number was found during the first week of April $(72.33 \pm 2.52)$ with a range of $(70$ $75)$ individuals $/ 45$ leaves in highly temperature $19{ }^{0} \mathrm{C}$ and $73 \%$ of R.H\%.

On the contrary, the mean number of whitfly individuals was low $(1.33 \pm 0.58)$ by the mid of January and this number increased and reached $(53 \pm 2.65)$ insects/ leaf by the first week of April.

Statistical analysis showed that there were highly significant differences between the inspections date of the leafminers and whitefly. The relationship between the leafminer individuals were positive with either the temperature or the relative humidity $(r=0.57$ and 0.09$)$, respectively.

A same trend was found with the whitfly individuals, the relationship was positively strong ( $\mathrm{r}$ $=0.68$ and 0.09 , respectively) between this insect and either the temperature or the R.H.\% (Table,3).

Results in Table (3) demonetrated the highly occurring individuals mean number of C.baeticus and E. zinckenella on garden pea pods along with all the periods of performed inspections in season (20142015). Whereas, the estimated population densities of insect- pods were more or less high in most of the periodic intervals of the conducted inspections. According to the prevailing conditions in this locality, these calculated densities were relatively the highest mean numbers of $(2 \pm 1)$ and $(55 \pm 5)$ insect/ pod throughout 7 th of April 2015.

Statistical analysis indicated positive relationship between the prevailing temperature and the mean number of pod borers C.baeticus and E. zinckenella $(\mathrm{r}=$ 0.32 and 0.73 respectively), 


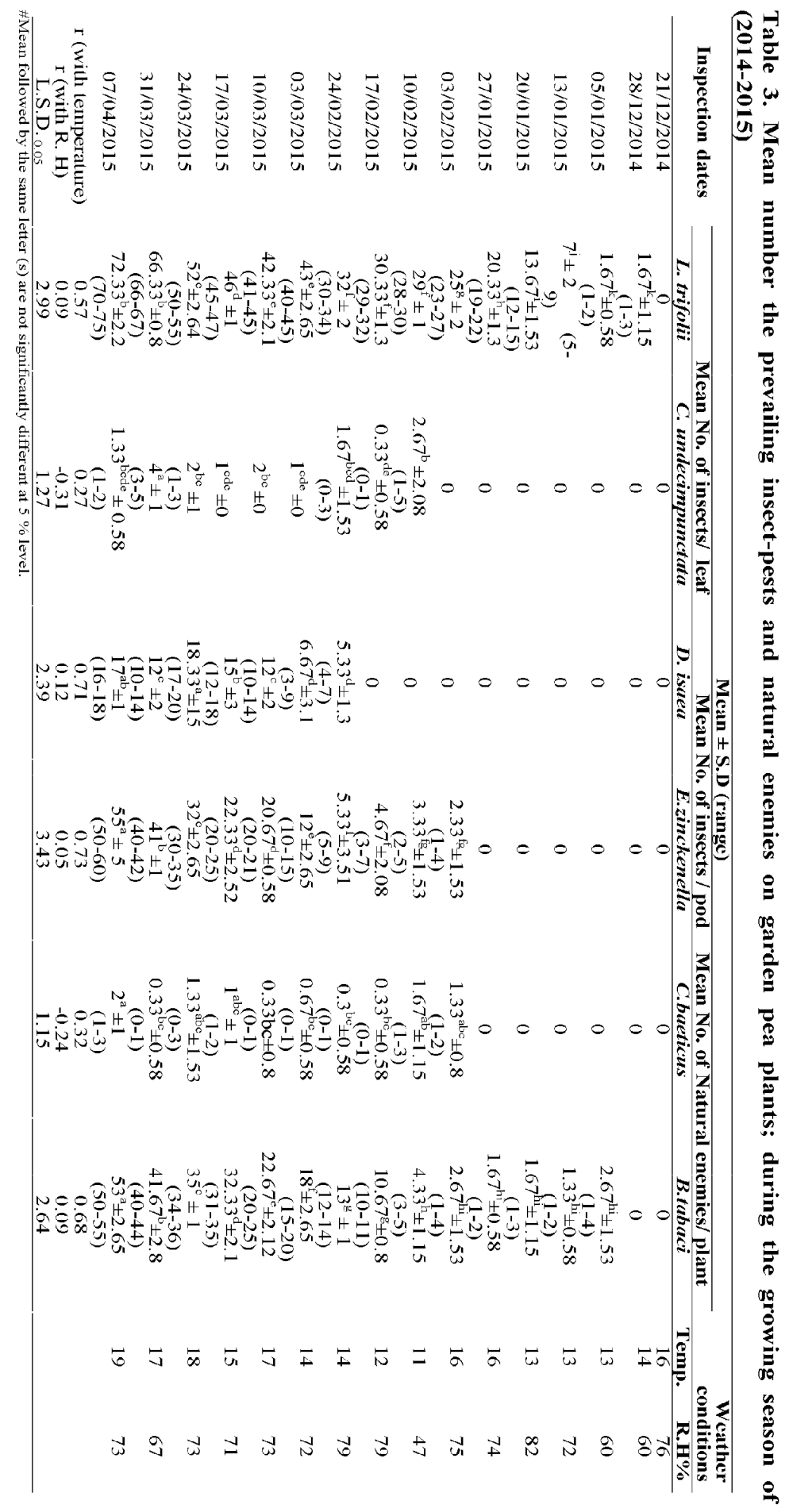




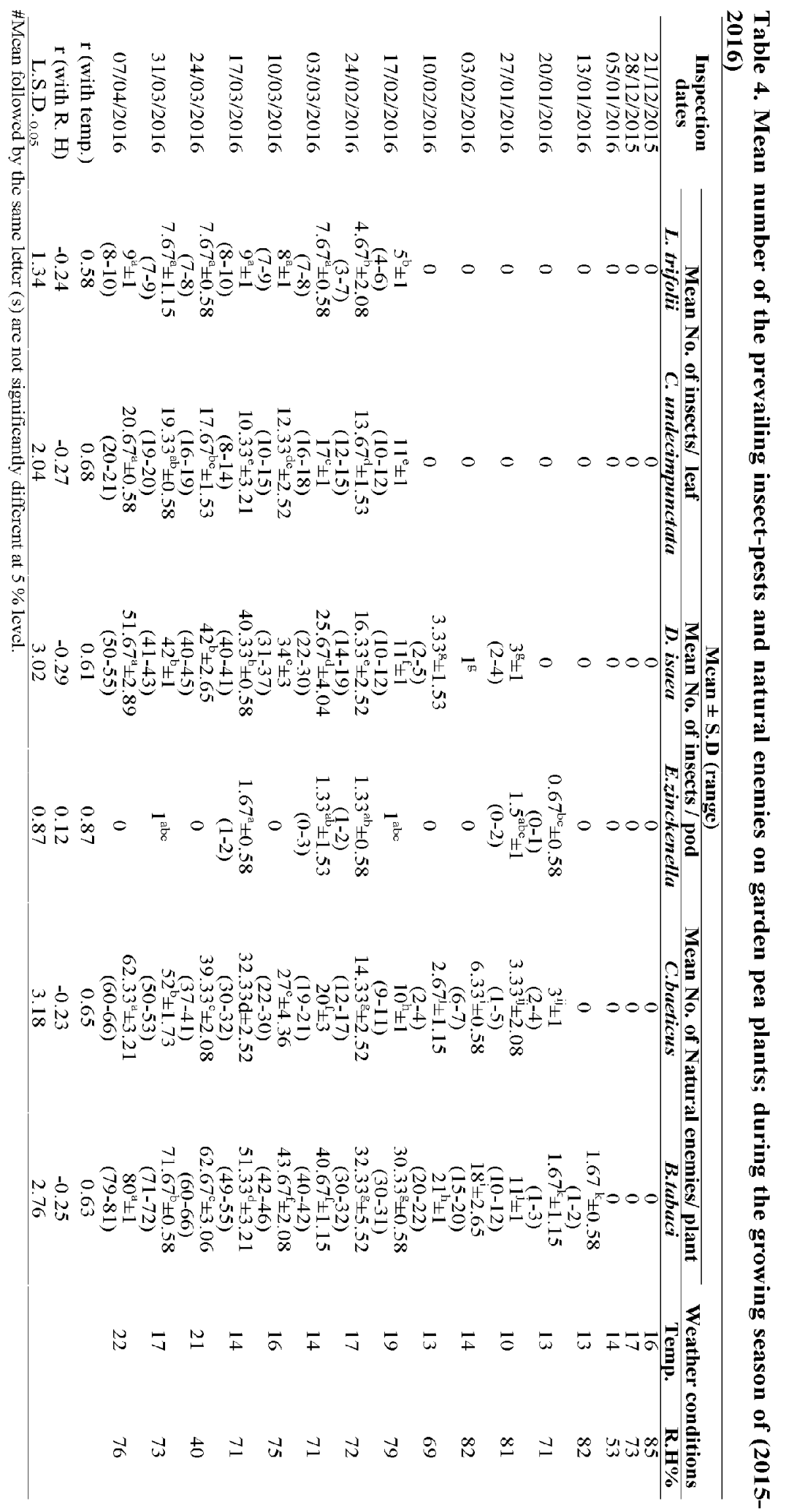


while the correlation coefficient was negative with the relative humidity $\mathrm{r}=-0.24$ with $C$. baeticus insect and positive with E. zinckenella $\mathrm{r}=0.05$, respectively.

From the listed results in Table(3), it could be easily noticed that the prevalent beneficial insect-species on garden pea plants $D$. isaea was along the growing season givin the highest calculated mean number $(18.33 \pm 1.5)$ individuals on 24 th of March at the prevailing temperature of $18^{\circ} \mathrm{C}$ and $73 \%$ R.H\%. (table,3).

While, the highest mean number of $C$. undecimpunctata was in the last day of March $(4 \pm 1)$ with a rang of (3-5insects $/ 15$ plants) at $17^{\circ} \mathrm{C}$ and $67 \%$ R.H\%.

The relationship between the $D$. isaea individuals were positive with either temperature or the relative humidity ( $\mathrm{r}=0.71$ and 0.12 , respectively).

Statistical analysis referred to thes a positive relationship between the prevailing temperature and the number of $C$. undecimpunctate individuals $(\mathrm{r}=0.27)$, while the correlation coefficient $(r=-0.31)$ was negative with the relative humidity R.H.\%(Table, 3 ).

It have been mentioned before that the level of the leafminer and whitefly were very low by the $3 \mathrm{rd}$ week of January in the season of (2015-2016), it would be necessary to detect its level with the other insects attacking and related to the garden peas as a host. The population densities of those insects were inspected during the growing season, which started by the end of December 2015, till the first week of April 2016 (Table,4). The highest levels of leafminer and whitefly were recorded in the first week of April $(80 \pm 1)$ and $(62.33 \pm 3.21)$ with a range of $(79-81) \&(60-66)$ individuals / 45 leaves at $22^{\circ} \mathrm{C}$ and $76 \%$ R.H\% (table, 4).

Statistical analysis showed a strong positive relationship ( $\mathrm{r}=0.63 \& 0.65$ ) between the prevailing temperature and number of leafminers and whitefly individuals, while the correlation coefficient was negative $(r=-0.25 \&-0.23)$ with the relative humidity (R.H.\%).

C. baeticus began to appear on 20 th of January and then the population dropped to zero in th $2^{\text {nd }}$ week of February and then began to appear for the last time in the middle of march, recording the highest levels of ( $1.67 \pm 0.58)$ with a range of ( $1-2$ insects $/ 45$ pods $)$ at the prevailing temperature of $14{ }^{0} \mathrm{C}$ and $71 \%$ R.H.\% (table,4).

Conversely, the mean number of $E$. zinckenella individuals was high and started to increase by the end of January $(3 \pm 1)$ at the prevailing temperature of $10^{\circ} \mathrm{C}$ and $81 \%$ R.H\%,the relationship between the mean number of this insects and the prevailing temperature was highly positive $(r=0.87 \& 0.61)$ (Table,4).

There was a negative correlation $(r=-0.29)$ between the prevailing relative humidity(R.H.\%)and the number of individuals of E. zinckenella meanwhile, there was a lower positive relationship between R.H. and C. baeticus $(\mathrm{r}=0.12)($ Table, 4$)$.

Regarding the other insects (natural enemies) on garden peas, it could be stated that the number of $D$. isaea started to grow up as the temperature and relative humidity increase.The highest mean number (20.67士 $0.58) / 15$ plants was found during the first week of April at the privialing temperature of $22{ }^{\circ} \mathrm{C}$ and $76 \%$ R.H\%.

On the other hand, C. undecimpunctata increased as the temperature increased reaching the highest mean number of ( $9 \pm 1$ insect/ plant) at the temperature of 22 and $76 \%$ R.H. (table,4).

The number of $D$. isaea and $C$. undecimpunctata increased as the temperature increased giving a positive correlation of $(r=0.68$ and 0.58$)$ individuals. There was a negative relationship $r=(-0.27$ and -0.24$)$ between the prevailing relative humidity R.H. (Tabl,4).

\section{CONCLUSION}

From the above demonstrated results it could be mentioned that the highest recorded number of inspected insect-pests on faba bean plants foliage was leaf miners, vs. the lowest recorded of E. lybica throughout season (2014-2015).

It is worth mentioning that this study must be a preliminary step in initialins the so-called(surveillance system) (Zaghloul, 1982 )for insect -pests on the country level of Egypt.

It is of importance to conclude that the aforementioned objectives are needed for the determination of economic injury level (EIL) and the economic threshold (ET) ]in future studies. Such economic thresholds are considered as salient factors in initialing an integrated pest control (IPM) program.

\section{REFERENCES}

A.O.A.D. 2012. Arab Organization for Agriculture Department . Statistics Yearbook, 2012. 16: 97.

Doss, A.S., K.M.Adam, F. A. Herakly and M.A.El - Hamky. 1992. Population densities of the broad bean leafminer Liriomyza trifolii (Burgess) and the cotton whitefly, Bemisia tabaci (Genn.) on protected cultivars. Minia Agric. Res.\& Dev., 14(3): 787- 797.

FAO. 2014. Statistical year book, world food and agriculture. Food and Agriculture organization of the united Nations, Rome, 567P. 
Köpke, U. and Nemecek, T. 2010. Ecological services of faba bean. Field Crops Research 115: 217-233.

Lanzoni, A.,A. Masetti,D. Plankesteiner and G. Burgio. 2003. Role of field margin habitats and annual flowering plant mixture on parasitization of economic Agromyzid pests. Bulletin OILB/ SROP; 26(4):95-100. 12 .

Pellet, P.L. and S. Shadarevian. 1970. Vegetables composition tables. In: Food composition, Tables for use in the middleeast American University of Beirut, Lebanon.pp.116.

Schuster, D.J.and K.J.Patel .1985. Development of Liriomyza trifolii (Diptera:Agromyzidae) larvae on tomato at constant temperatures. Flor. Entomol., 68(1): 158-161.
Steel, R. G. D. and J. H. Torrie. 1981. Principles and procedures of Statistic: Abiometrical approach. $2^{\text {nd }}$ Ed.Mc.Graw.Hill Kogahusha Ltd. pp.633.

Zaghloul,A.O. 1982. Biology of Earias vittella (Fab.)(Lep; Noctaidae) and assessment of losses in cotton due to bollworms.PHD.Thesis Faculty of Agriculture University of Agric. Sci.,Bangabe, India.

Zeghoueane,O. 1991. The situation of faba bean (Vicia faba L.) in Algeria. CIHIEAM, Options Mediterraneennes.

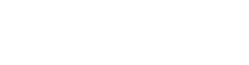

\section{التغيرات الهدية الموسمية للفٔفل الهشربة المتولجهفي زراعلت نبلتات الفر والبسلة

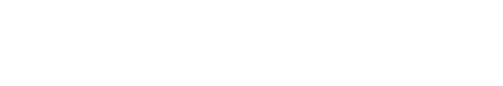

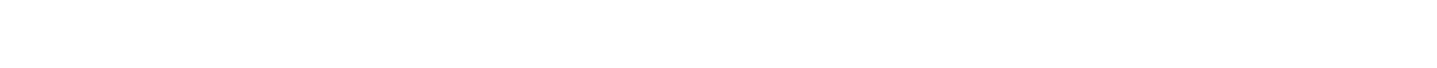

الأجنحة Hymenoptera، شبكية الأجنحة

. Coleoptera وغمدية الاجنحةNeuroptera

وقد وجد أن تعداد أفراد المن كلن الأعلي خلال موسمي

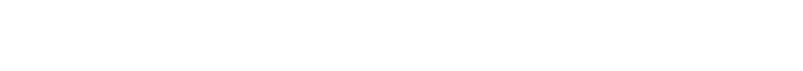

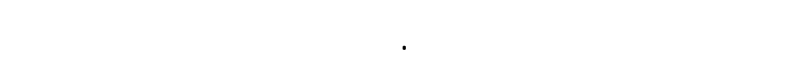

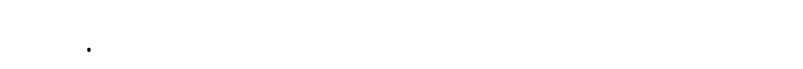

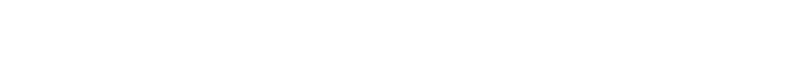

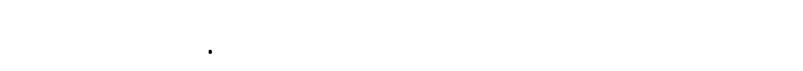

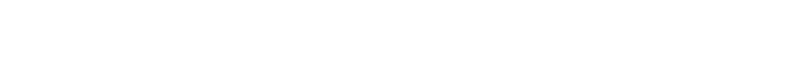
الأصابة في قرون البسلة.

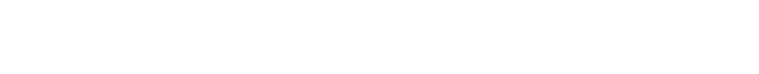

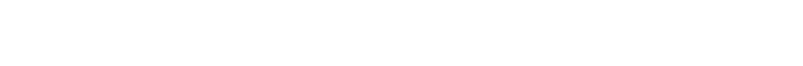
الاعلي في معل الإنتشار والتولجد Diglyphus isaea العددى متبوعا بالتولجد العددي الافل لكلا من هشرة لـألسد المن Coccinella Chrysoperla carnea undecimpunctate
في هذه الدرلسة لجري حصر لأهم الأفلت الهشرية والأعداء الطبيعية الموجوة علي نباتلت الفول والبسلة أثناء

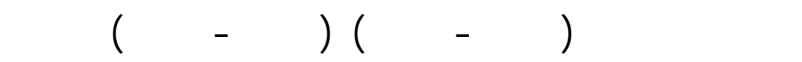
أبيس بمحاظة الأسكندرية - مصر وأمكن التعرف علي

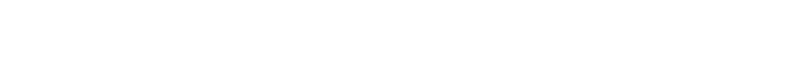

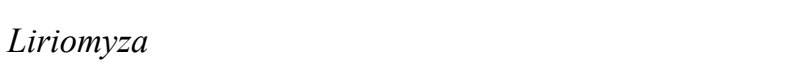

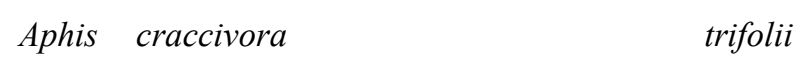

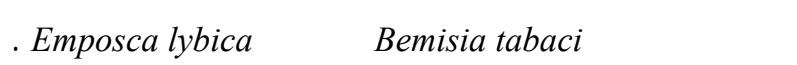
كما قم تصنيف والتعرف علي نوعين من الهشرات التي تصيب المجموع الخضري لنباتت البسلة وهي: صانعلت أفلق الاورق Liriomyza trifolii والذبابة البيضاء Bemisia tabaci

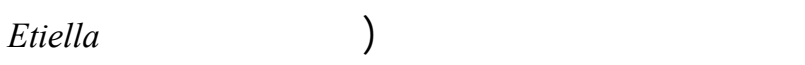
(Cosmolyce baeticus وأبو دقيق البقوليت zinckenella الني تصيب قرون نباتلت الفول والبسلة. كذلك أمكن التعرف علي ّ أنواع من الأعداء الطبيعية اللثائعة والتي تتنمي إلي كل من الرتب التاية: غثائية 